\title{
Mandando Montesquieu às favas: 0 caso do não cumprimento dos preceitos constitucionais de independência dos três poderes da república*
}

\author{
Ivan Antônio Pinheiro** \\ Luciano José Martins Vieira*** \\ Paulo Cesar Delayti Motta****
}

SumÁrio: 1. Introdução; 2. As transações entre os poderes do Estado: de Aristóteles a Montesquieu; 3. Características gerais do presidencialismo brasileiro; 4. Quando o Executivo usurpa o poder legiferante; 5. Quando o Judiciário usurpa o poder legiferante; 6. Algumas considerações críticas.

Summary: 1. Introduction; 2. The transactions between the powers of the State: from Aristotle to Montesquieu; 3. General characteristics of the Brazilian presidentialism; 4. When the Executive usurps the Legislative power; 5. When the Judiciary usurps the Legislative power; 6 . Some critical remarks.

Palavras-chave: Montesquieu; usurpação de poder; Executivo; Legislativo; Judiciário.

KEY wORDs: Montesquieu; usurpation of powers; Executive; Legislative; Judiciary.

A divisão entre as funções de legislar, de executar e de se manifestar, julgando os conflitos, bem como entre as atividades necessárias à gestão do Estado em um ambiente de res publica, difundida como divisão de poderes, com atribuições precípuas,

\footnotetext{
* Artigo recebido em nov. 2009 e aceito em fev. 2011.

** Professor associado do Programa de Pós-Graduação em Administração da Escola de Administração da Universidade Federal do Rio Grande do Sul (UFRGS). Doutor em administração pelo PPGA/EA/UFRGS. Endereço: rua Washington Luiz, 855/444 - CEP 90010-460, Porto Alegre, RS, Brasil. E-mail: iapinheiro@ea.ufrgs.br.

*** Mestrando em administração pelo PPGA/EA/UFRGS. Bacharel em administração (UFRGS) e bacharel em ciências jurídicas e sociais pela Pontifícia Universidade Católica do Rio Grande do Sul (PUC/RS). Endereço: rua Washington Luiz, 855/444 - CEP 90010-460, Porto Alegre, RS, Brasil. E-mail: ljmvieira@yahoo.com.br.

$* * * *$ Professor adjunto do PPGA/EA/UFRGS (aposentado). Mestre em public administration pela New York University. Endereço: rua Washington Luiz, 855/444 — CEP 90010-460, Porto Alegre, RS, Brasil. E-mail: delayti@hotmail.com.
} 
porém não exclusivas a cada um, é lição antiga deixada por Montesquieu para evitar a tirania do soberano estatal. No caso brasileiro, apesar de a Constituição Federal de 1988 ser considerada a Constituição Cidadã, ela apresenta vícios de origem, sendo o de maior repercussão o fato de ter adotado o sistema presidencialista de governo, mas atribuindo ao Congresso competências próprias aos sistemas parlamentaristas. Tal desenho, por si eivado de contradições, aliado à tradição e ao peso do direito civil vis-à-vis ao dos usos e costumes, e em que pese ser um Estado federado, faz com que haja um excesso de competências a cargo da União. Diante desses vícios e contradições, este artigo mostra, a partir de pesquisa bibliográfica e dados secundários, como a interdependência entre os três poderes acabou se tornando um processo descontrolado de usurpação das atribuições e competências uns dos outros. Assim, é feito um pano de fundo estabelecendo os principais aspectos das postulações de Montesquieu e como tais aspectos estão presentes no sistema de governo do modelo tripartite, o presidencialismo, com destaque para as peculiaridades do contexto brasileiro, enfatizando importantes questões institucionais do sistema político nacional: multipartidarismo em um sistema federal bicameral; o elevado número de partidos; a dificuldade de, como resultado direto da consulta popular, um partido obter a maioria nos respectivos parlamentos; alianças parlamentares funcionais-fisiológicas; e o caráter nacional dos partidos. Posteriormente, são discutidos exemplos de como o Executivo usurpa o poder de legislar via medidas provisórias que acabam interferindo na agenda do Legislativo, em que pese a exigência constitucional de utilização deste instrumento somente em casos de urgência e relevância; de como o Judiciário também acaba legislando em razão da omissão do Parlamento em questões importantes; e de como o Judiciário não só força o Executivo a estabelecer e a implementar estratégias de ação, como assume ações que são de sua competência original. O quadro, como se percebe, é complexo; neste ambiente, as interferências de um poder nos domínios do outro são antes consequência do que fato originário. Isso impacta sobremaneira a formulação e implementação de políticas públicas, veja a ampla divulgação do que ocorre nas áreas da saúde e execução das penas privativas de liberdade em presídios. O modelo tripartite propaga o equilíbrio dos poderes, sem concentração nem separação absoluta entre eles, o que atualmente não vem ocorrendo no país.

Sending Montesquieu over the board: the case of non-conformity to the constitutional precepts of independence among the powers of the republic

The division among the legislative, executive and judicial functions, as well as among the activities necessary to administrate the State in an environment of res publica, known as division of powers, with mutual tasks but not exclusively to each one, is an old lesson left by Montesquieu. In the Brazilian case, although the 1988 FC is considered as being the Citizenship Constitution, it presents problems of origin, being the fact of having adopted a presidential form of government but having attributed to the Congress competences appertaining to parliamentary systems the major one. Such a design, per se full of contradictions, allied to the tradition and the weight of the civil vis-à-vis the uses and costumes law and, although being a Federate State, 
results in an excessive amount of competences in the Union's hands. Having in sight these vices and contradictions, this paper discusses, based on a bibliographic research and secondary data, how the interdependency among the three Powers resulted in an out of control process of usurping the attributions and competences one from the other. Thus, a basic tableau is presented establishing the main points of Montesquieu's postulations and how these aspects are present in the tripartite model of government, namely presidentialism, highlighting the peculiarities of the Brazilian context, emphasizing some important institutional aspects of the national political system: multipartidarism in a bicameral federal system; the great number of parties; the difficulty of, as the result of a popular consultation, a single party getting a majority in both parliamentary houses; functional-physiological parliamentary alliances; and the parties national character. Afterwards, some examples are discussed on how the Executive usurps the legislative power via Provisional Measures which end up clogging the Legislative agenda, although the Constitutional text postulates that the usage of this instrument be only in cases of urgency and of relevance; how the Judiciary also ends up legislating because of the Parliament's omission in important matters; and as how the Judiciary not only press the Executive to establish and implement action strategies, as well as assumes actions that are of its original competency. The scenario, as it can be perceived, is quite complex; in this environment, the interferences of a Power upon the dominions of another are much more consequence than original fact. This impact heavily upon the formulation and implementation of public policies, as has been shown by the divulgence about what is happening in the areas of health and the execution of the liberty restricting penalties in prisons. The tripartite model postulates the equilibrium among the powers, with neither concentrating nor having an absolute separation among them, which is not being the case nowadays in the country.

\section{Introdução}

A divisão entre as funções de legislar, de executar e de se manifestar, julgando os conflitos, bem como entre as atividades necessárias à gestão do Estado em um ambiente de res publica, difundida como divisão de poderes, com atribuições precípuas, porém não exclusivas a cada um, é lição antiga deixada por Montesquieu que procurava, assim, evitar qualquer forma de tirania, e hoje é considerada um mandamento básico e elemento estrutural ao Estado democrático e de direito. A citação seguinte é uma das que melhor ilustra o pensamento de Montesquieu (2006:166):

Quando na mesma pessoa, ou no mesmo corpo de magistrados, o poder legislativo se junta ao executivo, desaparece a liberdade; pode-se temer que o monarca ou o senado promulguem leis tirânicas, para aplicá-las tiranicamente. 
Não há liberdade se o poder judiciário não está separado do legislativo e do executivo. Se houvesse tal união com o legislativo, o poder sobre a vida e a liberdade dos cidadãos seria arbitrário, já que o juiz seria ao mesmo tempo legislador. Se o judiciário se unisse com o executivo, o juiz poderia ter a força de um opressor. E tudo estaria perdido se a mesma pessoa, ou o mesmo corpo de nobres, de notáveis, ou de populares, exercesse os três poderes: o de fazer as leis, o de ordenar a execução das resoluções públicas e o de julgar os crimes e os conflitos dos cidadãos.

Ao seu tempo e ao seu modo, cada povo criou uma gramática própria para operar o sistema político vigente, havendo, pois, incontáveis modelos de instituições bem como de relacionamentos que entre elas foram sendo estabelecidos. Este artigo se propõe a analisar a questão apontada por Montesquieu tendo como foco a experiência brasileira nos anos mais recentes, com os casos que o ilustram tendo sido colhidos no período conhecido como Nova República - após 1985.

Ulysses Guimarães, ex-deputado e presidente da Assembleia Nacional Constituinte, entre outros, pelos inúmeros direitos individuais e sociais inscritos em seu texto, saudou a CF de 1988 como a Constituição Cidadã. Já outros, como Prado (1994), percebem no excesso de direitos um dos principais vícios de origem no texto constitucional. Todavia, o problema de maior repercussão foi o fato de ter sido adotado o sistema presidencialista de governo não obstante terem sido atribuídas ao Congresso competências próprias aos sistemas parlamentaristas. Tal desenho, por si eivado de contradições, aliado à tradição e ao peso do direito civil vis-à-vis ao dos usos e costumes, e em que pese ser um Estado federado, haver um excesso de competências a cargo da União, foram determinantes para que, na época (1988), o texto constitucional fosse gravado com a previsão de que em 1993 fosse realizado um plebiscito para a escolha da forma de governo, se monarquia ou república, e do sistema de governo, se presidencialismo ou parlamentarismo. Como resultado desse quadro, o então presidente José Sarney vaticinou que o país tornar-se-ia ingovernável, condição também salientada por Skidmore (apud Prado, 1994:preâmbulo, s/n): "O problema do Brasil não é de homens nem de recursos. É da Constituição de 1988. Ela tornou o Brasil rigorosamente ingovernável. Pior: nas mãos de um aparelho político permissivo que manipula um sistema administrativo ultrapassado".

As urnas referendaram o regime vigente: uma república presidencialista. Houve então a distorção de haver simultaneamente um sistema presidencialista de governo e um Congresso com funções de sistema parlamentarista. 
Restou então evidente que muitas reformas à Constituição seriam necessárias, entre elas a das instituições políticas, sem as quais as relações entre os poderes, os governos da União e dos estados membros ficariam seriamente comprometidas.

Desde então, outras características institucionais, também apontadas como deficiências e limitações do sistema político brasileiro, têm contribuído, se não para um permanente estado de crise e de instabilidade institucional, no mínimo para um quadro de persistente confronto entre os poderes, com repercussões nocivas que se estendem para todo o ambiente econômico e social do país. Como exemplos mais significativos há as seguintes situações: 1 . ausência de cláusula de barreira aos partidos; 2 . existência de 27 partidos políticos ativos, o que praticamente inviabiliza a construção de maiorias de sustentação governamental; 3. possibilidade de formar alianças e coligações políticas de oportunidade, isto é, somente para o pleito eleitoral da ocasião (se nacional, estadual ou municipal), independentemente das proposições estatutárias; 4. inexistência de um mecanismo de recall; entre outras.

Nesse cenário, o processo legislativo evolui a passos lentos, o que motiva e tem justificado, na perspectiva do Poder Executivo, o recurso, com frequência, a um instrumento de exceção: a medida provisória, que é um documento que desde sua edição é dotado de força de lei e que, por isso, deve ser apreciado em até 60 dias pelo Poder Legislativo; em não o sendo, desde então obstaculizará a pauta dos encaminhamentos. As repercussões dessas iniciativas não são desprezíveis na vida das instituições, a começar pela constatação de que, atualmente, no que é relevante, através das medidas provisórias, é o Poder Executivo quem tem definido a agenda de prioridades do Congresso e, efetivamente, legislado no país.

Por outro lado, na ausência de produção legislativa própria, os vícios constitucionais já referidos, somados a outros, pouco a pouco foram se estendendo e comprometendo a vida de algumas instituições, a ponto de praticamente desfigurá-las à luz do que se entende teria sido a intenção do legislador constituinte. Diante desse quadro tem se insurgido a mais elevada corte do Poder Judiciário que, em resposta às arguições que lhe são encaminhadas ou se manifestando em nível de último recurso, estabelece ou resgata o que entende ser o "espírito da lei", atuando, dessa forma, como legislador. Com efeito, em 2004, a Corte Suprema redefiniu o quantitativo de representantes nas câmaras municipais e extinguiu mais de 8 mil cargos de vereadores; em 2006, obrigou que as alianças políticas firmadas para a disputa à presidência fossem também reproduzidas nos estados membros no processo de disputa pelos cargos de governador; em 2007, emitiu parecer indicando que os mandatos eletivos não 
pertencem aos parlamentares, e sim aos partidos. Todas essas decisões vieram ocupar o vácuo de iniciativas existente no Poder Legislativo e, além dessas, muitas outras iniciativas foram sendo tomadas.

Se as repercussões das iniciativas legislativas do Poder Executivo não são desprezíveis, muito menos o são as do Judiciário, pois a este não foi delegado o poder político; assim, tanto no plano da doutrina e dos princípios, quanto na práxis do funcionamento do Estado e dos governos, este é um tema que demanda estudo mais aprofundado. Nesse contexto institucional, duplamente confuso e inusitado, há que se destacar, também, o papel do Ministério Público, instituição que ganhou relevo no texto da Constituição de 1988 e que, a partir de demandas endossadas pelo Poder Judiciário, tem interferido, sobremodo, na agenda dos demais poderes.

A pesquisa bibliográfica e os dados secundários constituem a matériaprima deste artigo que analisa, discute e confronta o modelo de Montesquieu relativamente às características e necessidades de um ambiente onde elementos pós-modernos e valores globalizados convivem com práticas patrimonialistas típicas das sociedades pré-modernas, como é o caso da brasileira.

\section{As transações entre os poderes do Estado: de Aristóteles a Montesquieu}

A estratégia da separação do poder estatal, para evitar a tirania, não é nova, tendo sido sugerida, entre outros, por Aristóteles (384-322 a.C.), em sua célebre Política, em especial no Livro IV (cap. XIV a XVI), onde expôs que em todo governo deveriam existir três poderes essenciais e que o legislador prudente deveria acomodar da maneira mais conveniente para garantir um "bom governo", ou seja, que garantisse a ordem e a busca pelo bem comum. Textualmente: "Toda Cidade tem três elementos, cabendo ao bom legislador examinar o que é mais conveniente para cada constituição [...] A primeira dessas partes concerne à deliberação sobre os assuntos públicos; a segunda, às magistraturas [...] por último relaciona-se como deve ser o poder judiciário" (Aristóteles, 2006:170). Adiante, quando se refere "à parte deliberativa [como] poder soberano nas Cidades" (Aristóteles, 2006:172), não deixa dúvidas acerca da primazia deste sobre os demais.

Inúmeros acontecimentos, a exemplo da Magna Carta (1215) e do que resultou no Bill of Rights (1689), selarão a redução do poder do monarca, inicialmente diante de um conselho que, com o tempo, evolui para um parlamento, primeiro indicado, temporário e, posteriormente, eleito pelos cidadãos 
e permanente. Na Inglaterra, o Parlamento, desde as suas origens medievais, sempre foi uma instituição presente, em alguns períodos atuando ativamente em termos de iniciativas políticas, em outros, subordinado ao poder real.

Entretanto, a teorização moderna sobre a divisão dos poderes ocorreu somente no século XVII, quando Locke (2006) retoma o tema em seu Segundo tratado sobre o governo, ao propor a bipartição dos poderes, ou seja, a separação do Legislativo da influência do poder do monarca inglês, o Poder Executivo. O primeiro é o que tem o direito de determinar como a força do Estado será empregada na defesa da comunidade e dos seus membros, através de leis elaboradas por representantes (no todo ou em parte escolhidos pelo povo mediante eleição para mandato com prazo estabelecido) que não estejam reunidos constantemente, de modo a evitar a tentação de tomada do poder por parte daqueles que têm a missão de elaborar as leis que vigoram permanentemente. O Poder Executivo é atribuído a uma única pessoa, o monarca, que acumula as seguintes funções que necessitam potencialmente do emprego da força: a) função executiva, que está sempre em exercício e que garante a execução das leis; b) função federativa, que trata da política e das relações internacionais (guerra e paz, de realizar ou desfazer ligas e alianças); c) função política, que é a prerrogativa de o governo agir, segundo sua discrição, em prol do bem público, fora do prescrito pela lei e, algumas vezes, contra aquilo por ela disposto (Locke, 2006).

No modelo da bipartição dos poderes, há a supremacia do Legislativo sobre o Poder Executivo quando este não fizer parte do primeiro. Em tendo o monarca participação no Legislativo, ele não pode ser um poder superior ao equilíbrio que deve existir entre os dois poderes.

Na realidade inglesa após a Revolução Gloriosa, conforme explicita Souza Junior (2002:59):

os órgãos políticos estavam separados (Rei, Casas Legislativas e Altas Cortes), mas operavam juntos no mesmo e unificado espaço institucional: o Parlamento. Os três poderes eram órgãos de uma única e mesma instituição - o Parlamento. Compartilhavam da mesma soberania. A cooperação entre eles decorria tanto do ambiente favorável comum que dividiam quanto — não há esconder - dos virtuais, mas nem por isso menos eficazes, constrangimentos da instituição unificante e envolvente sobre cada um dos poderes individualmente. (grifo do autor)

No século seguinte, em 1748, em Do espírito das leis, Montesquieu propôs um modelo institucional para a França durante o regime absolutista de 
Luís XV que viabilizasse a liberdade política do cidadão diante do Estado. Para Montesquieu (2006:165):

Há em cada Estado três espécies de poder: o poder legislativo, o poder executivo das coisas que dependem do direito das gentes, e o poder executivo daquelas que dependem do direito civil. Pelo primeiro poder, o príncipe ou magistrado cria as leis para um tempo determinado ou para sempre, e corrige ou ab-roga aquelas que já estão feitas. Pelo segundo, determina a paz ou a guerra, envia ou recebe embaixadas, estabelece a segurança, previne as invasões. Pelo terceiro, pune os crimes ou julga as questões dos indivíduos (Montesquieu, 2006:165).

De acordo com Souza Junior (2002:59):

Os poderes, para Montesquieu, deveriam estar separados funcionalmente, ou seja, cada função seria atribuída a cada órgão da forma mais especializada possível. E os poderes deveriam estar separados organicamente: os órgãos deveriam ter independência recíproca, equipotência, num radical pé de igualdade, a separação orgânica e separação funcional criariam um círculo de causação circular, de que resultaria uma ordem política com liberdade e concórdia. (grifos do autor)

A liberdade de cada um dos poderes políticos seria limitada pela liberdade dos demais: "Para que não se possa abusar do poder, é preciso, pela disposição das coisas, que o poder contenha o poder. Uma constituição pode ser feita de tal forma, que ninguém será constrangido a praticar coisas que a lei não obriga, e a não fazer aquelas que a lei permite" (Montesquieu, 2006:164165). Tal liberdade ensejaria "um movimento natural das coisas, uma mão invisivel, apta a proporcionar, necessária e independentemente de qualquer poder superior de autoridade, a garantia da própria liberdade e a indução da harmonia e da concórdia" (Souza Junior, 2002:60). Essa liberdade é que daria a unidade de atuação dos poderes de estado, substituindo o papel do Parlamento inglês no modelo bipartite.

Importante destacar que em momento algum da sua obra Montesquieu defendeu a separação absoluta dos poderes de Estado, o que inviabilizaria a unidade estatal. O que ele quis expor foi que a reunião de tais poderes em um único órgão tem como resultado a tirania, o que inviabiliza a liberdade do indivíduo perante o Estado. Em que pese haver em Locke e em Montesquieu o tema em comum, a divisão dos poderes de Estado, há entre eles uma diferença fundamental, conforme assinala Aron (2002:23): 
Entre Locke e Montesquieu, porém, há uma diferença fundamental da intenção. O objetivo de Locke é limitar o poder real, mostrar que se o monarca ultrapassa certos limites ou desrespeita determinadas obrigações, o povo, fonte verdadeira da soberania, tem o direito de reagir. A ideia essencial de Montesquieu, porém, não é a separação de poderes no sentido jurídico, mas o que se poderia chamar de equilíbrio dos poderes sociais, condição da liberdade política.

Contudo, John Stuart Mill, em O governo representativo (2006), destaca a relevância singular do parlamento como instituição do Estado moderno, traduzindo a força e a atualidade da visão precursora de Aristóteles, conforme já citado.

Nos Estados modernos que adotaram a tripartição dos poderes ocorreu um resgate da interface proposta por Montesquieu: cada um dos poderes de Estado possui uma função precípua, mas não vedada ao exercício de outras atribuições que podem ter pontos de contato ou estritamente ligadas às de outro poder. Nesse sentido, Menezes (1996:258) pontifica que:

O legislativo faz a lei, porém o executivo pode propô-la ou vetá-la e o judiciário pode julgá-la nula. O executivo realiza a administração, todavia pode o legislativo organizar os serviços que lhe são inerentes e o judiciário nomear os seus próprios funcionários. O judiciário efetua os julgamentos, contudo pode o legislativo modificar-lhe os critérios legais e o executivo participar de justiça, indultando ou comutando penas.

No modelo tripartite os poderes funcionam melhor em conjunto e a ação de um detém ou limita a ação do outro. Há, portanto, a necessidade de um equilíbrio entre os poderes de Estado, equilíbrio esse estabelecido e consagrado na atual Constituição brasileira. Assim, se faz necessário comentar como aconteceu o processo constitucional brasileiro após o período militar, e também como se caracteriza nosso presidencialismo, já que o presidencialismo é o sistema de governo do modelo tripartite.

\section{Características gerais do presidencialismo brasileiro}

O sistema de governo presidencialista é, para Abranches (apud Cintra, 2007:65), uma das "bases de nossa tradição republicana", assim como o federalismo, o bicameralismo, o multipartidarismo e a representação proporcional. Tais institutos expressariam as necessidades e contradições de natureza social, 
econômica, política e cultural que identificam histórica e estruturalmente o processo de formação da sociedade brasileira.

Conforme Moraes (2004) e Cintra (2007), são características básicas do presidencialismo (todas encontradas no sistema brasileiro):

v ser um sistema de governo que tem como referencial teórico o modelo clássico da separação de poderes elaborado por Montesquieu;

- consagrar na figura do presidente da república a chefia de Estado e a chefia de governo. O presidente, como chefe de Estado, representa a nação em suas relações internacionais e corporifica a unidade interna do Estado. Como chefe de governo, é o responsável pelo exercício das funções de governo (de natureza política interna e de natureza eminentemente administrativa);

- prever a escolha do presidente em eleição popular;

v garantir a independência entre o Executivo e o Legislativo. No presidencialismo, o Poder Executivo concentra-se na pessoa do presidente, que o exerce, em regra, sem responsabilidade política perante o Poder Legislativo, uma vez que seu mandato e os dos parlamentares são prefixados. O Legislativo não pode ser dissolvido pelo presidente, e este só pode perder o mandato na hipótese de impeachment. Também não cabe ao Poder Legislativo demitir ou influir na escolha dos auxiliares diretos do presidente (ministros, secretários);

v poder responsabilizar penal e politicamente o presidente da república.

Verifica-se, portanto, que é inerente ao sistema uma nítida separação entre o Executivo e o Legislativo. Porém, é fundamental ressaltar que tal separação não significa a ausência da necessidade de coordenação das diversas ações destes poderes, pois um dos princípios basilares do estado democrático de direito é o princípio da legalidade, qual seja, a ação dos agentes públicos orientada conforme o disposto na lei, devendo esta ser apreciada e votada no Parlamento como forma de sinalizar a vontade da maioria. Embora caiba ao Executivo a iniciativa de propor e modificar muitas leis necessárias à operação (gestão) do Estado, bem como para implementar as políticas públicas na esfera da sua competência, aquele depende do Parlamento pois, conforme dito, é a este que cabe a aprovação de suas iniciativas, convertendo-as, por fim, em lei. Destarte, os chefes do Executivo necessitam de maioria parlamentar para aprovar as leis que darão o indispensável suporte ao projeto de governo vitorioso no processo eleitoral. No caso brasileiro, a formação dessa maioria 
é dificultada por questões institucionais do sistema político que, já mencionadas, serão agora brevemente retomadas.

A primeira é o multipartidarismo em um sistema federal bicameral, o que, conforme a matéria, pode representar a necessidade de maioria em duas instâncias legislativas. Atualmente, são 27 partidos políticos ativos; na Câmara dos Deputados há representantes de 22 agremiações e no Senado Federal há 16 partidos com assento (Brasil, 2011a, 2011b, 2011c). O elevado número de partidos que, isolados ou em coligações, estão autorizados a disputar os pleitos eleitorais implica grande dificuldade de, como resultado direto da consulta popular, um partido obter a maioria nos respectivos parlamentos que, no Brasil, caso único de federação, estão organizados em três níveis: União, estados e municípios - elemento que acirra as disputas na medida em que amplia os jogos de interesses conflitantes e seus desdobramentos em estratégias para atingir os respectivos objetivos.

Assim, de origem, o desenho institucional brasileiro, se não inviabiliza, dificulta a construção de maiorias legislativas estáveis, as quais, imediatamente após os pleitos, começam a ser construídas em um exercício de engenharia política que se estende ao longo de toda a legislatura a fim de assegurar sustentação ao Poder Executivo. Longe de ser um processo espontâneo e programático para formar a base legislativa de apoio, não resta ao Executivo senão lançar mão de outros expedientes, como a distribuição de cargos de direção e de assessoramento (de livre provimento) existentes na estrutura organizacional da administração pública brasileira. São cargos na administração direta, que inclui 37 entidades (24 ministérios, oito secretarias e cinco órgãos com status de ministério - como a Advocacia-Geral da União e o Banco Central), e na administração indireta, que abrange uma miríade de entidades, algumas mais cobiçadas que os próprios ministérios, a exemplo das estatais Petrobras, Banco do Brasil, BNDES, entre outras. Não restam dúvidas de que os interesses não se restringem à ocupação de cargos que, em que pese os bônus, trazem alguns ônus, mas, sobretudo, se estendem à utilização, com relativos graus de liberdade, dos orçamentos públicos a partir da possibilidade de (re)direcionar verbas de programas e projetos para as respectivas bases de apoio, sejam elas partidárias, regionais, setoriais ou mesmo para categorias e grupos da sociedade, por vezes mediadas por questionáveis triangulações institucionais, a exemplo das ONGs, algumas qualificadas como Oscip. Ademais, o fato de, no Brasil, os partidos possuírem caráter nacional, ao lado da dimensão continental do país, é determinante para que um mesmo partido abrigue diferentes posicionamentos e mantenha alianças regionais também distintas. Devido a 
essa situação, é natural que partidos aliados em determinadas regiões sejam, em outras, competidores acirrados.

Não sendo ideológicas e nem programáticas, mas antes funcionais-fisiológicas, as maiorias são instáveis e, não raro, guardam contradições. Exemplo destas é a atuação do Partido do Movimento Democrático Brasileiro (PMDB) no Congresso Nacional. No período de março de 1985 a dezembro de 2006, somente entre outubro de 1990 e outubro de 1992 e entre janeiro de 2003 e janeiro de 2004 o partido não teve representantes nos cargos de ministros (Amorim Neto, 2007). A participação do partido na chefia de ministérios foi constante de 2007 a 2010, tendo chegado, em 2011, à vice-presidência da República. Porém, apesar de tal formalização da participação no governo, é frequente a não adesão de parlamentares do partido em votações de interesse do Executivo, obrigando este, a cada votação, a negociar com parlamentares integrantes de um partido que formalmente é de sua base aliada, hoje integrada por 17 partidos.

Conforme Amorim Neto (2007:132), no Brasil, ao se analisar a formação ministerial de 1985 a 2006, "verifica-se que estes [os ministérios formados] são sempre arranjos multipartidários com maior ou menor grau de fragmentação e heterogeneidade ideológica". Não bastasse a dificuldade natural para gerir 37 ministérios, a titularidade destes é um espelho da fragmentação e da heterogeneidade ideológica partidária, especialmente os formados a partir de 1992, com as consequências que desse contexto podem advir. Quanto maior o número de partidos, maior é o esforço de articulação política do Executivo e, nesse quadro, contrário ao senso comum, os partidos com bancadas reduzidas reúnem grande força política, podendo definir uma votação, mormente as que requerem quórum qualificado, o que lhes confere, então, enorme poder de barganha no "balcão de negócios", em particular, na apreciação de temas polêmicos e de grande repercussão na sociedade. Não bastassem as dificuldades intrínsecas ao desenho institucional, há evidências de desvios de conduta, eis que o retrospecto político nacional demonstra que nem sempre a composição ministerial multipartidária assegura a fidelidade dos partidos aliados no Parlamento, uma vez que não há a garantia, devido ao voto ser secreto, de que todos os deputados da base aliada votem conforme os interesses do governo, obrigando, por isso, a existência de um estado permanente de negociação individual entre o Executivo e os "parlamentares aliados". Nesse contexto, as relações entre o Executivo e o Legislativo, nos três níveis e com raras exceções, se caracterizam pelo embate contínuo, quando não, pelo aberto confronto.

Mas, se o número de agremiações políticas tem sido um entrave às relações institucionais, por que se permite sua manutenção e mesmo ampliação? A resposta mais imediata é que tal se deve à ausência de uma cláusula de 
barreira, um dispositivo legal que estabeleça um número mínimo de votos para assegurar a existência de um partido ou de uma coligação no Parlamento. Neste sentido, a Lei no 9.096, de 19 de setembro de 1995 (Brasil, 1995), representou uma tentativa de solução, com uma previsão de validade a partir das eleições de 2006. Em 2006, o Supremo Tribunal Federal (STF) julgou que a cláusula de barreira, tal como concebida, era inconstitucional por ferir o direito de manifestação política das minorias e, desde então, o assunto não mais ocupou a agenda política.

Num ambiente como este em que até pouco tempo atrás havia plena liberdade de, praticamente a qualquer momento e por várias vezes, um parlamentar trocar de agremiação política e em que inexiste o instituto do recall, o que prevalece é a realpolitik.

Este sucinto quadro institucional do país demonstra a dificuldade que o presidencialismo de coalizão tem para fazer com que o Executivo consiga obter o apoio do Legislativo para a implementação do seu plano de governo. Na visão de Abranches (apud Cintra, 2007:66), o presidencialismo de coalizão, que pode ser tranquilamente denominado de "presidencialismo de colisão", seria um sistema de governo instável, de alto risco, pois está sempre na dependência do desempenho corrente e da disposição de "respeitar estritamente os pontos ideológicos ou programáticos considerados inegociáveis, nem sempre explícita e coerentemente fixados na fase de formação da coalizão".

\section{Quando o Executivo usurpa o poder legiferante}

No Brasil, a exemplo do que ocorre em outros tantos Estados, ao Poder Legislativo foram destinadas diversas atribuições, como a de dar posse aos titulares do Executivo, a de representar o país no exterior, a de mediar conflitos internos entre os agentes da sociedade, e a de exercer o controle externo (orçamentário) sobre os demais poderes. Todavia, é a função legislativa que propriamente o singulariza, pois, conforme prescreve o art. 59 da Constituição Federal (Brasil, 2005), a atividade legislativa abrange sete espécies normativas: 1. emendas à Constituição; 2. leis complementares; 3. leis ordinárias; 4. leis delegadas; 5. medidas provisórias; 6 . decretos legislativos; 7. resoluções. Excetuando as leis delegadas e as medidas provisórias, as demais atividades se reproduzem nas constituições estaduais e nas leis orgânicas municipais. Entre essas espécies, importa destacar as medidas provisórias (MPs) porque são as que efetivamente demonstram a ação legiferante do Executivo, usurpando, dessa forma, a função do legislativo. 


\subsection{As medidas provisórias}

A CF de 1988, em seu artigo 62, prevê que "em caso de urgência e relevância, o presidente da república poderá adotar medidas provisórias, com força de lei, devendo submetê-las de imediato ao Congresso Nacional" (Brasil, 2005:64). O § 3ㅇ do mesmo artigo esclarece e determina que "as medidas provisórias, [...] perderão eficácia, desde a edição, se não forem convertidas em lei no prazo de sessenta dias, prorrogável, nos termos do § 7ํㅡ, uma vez por igual período, devendo o Congresso Nacional disciplinar, por decreto legislativo, as relações jurídicas delas decorrentes" (Brasil, 2005:64). Trata-se, pois, como enuncia o caput, de um instrumento de excepcionalidade, concebido pelo legislador para dar agilidade ao Executivo quando a eficiência, a eficácia e a efetividade da gestão pudessem vir a ser prejudicadas em razão dos prazos habitualmente incorridos no trâmite do processo legislativo, que compreende os entendimentos e as negociações que antecedem a elaboração do projeto de lei, o debate público nas comissões pertinentes, a apreciação (se necessária) nas duas casas legislativas, a homologação e a promulgação (quando o caso) pelo Executivo, a possibilidade de veto parcial etc. Concebidas como instrumento excepcional, na prática, decorridos 23 anos de vigência constitucional, pode-se dizer que o Executivo banalizou sua edição, transformando-a praticamente em instrumento ordinário, sempre disponível para solucionar os mais diversos tipos de necessidades e impasses nem sempre urgentes e de relevância discutível. A título de informação, no período do mandato de Fernando Henrique Cardoso foram editadas 334 MPs, e no período de Lula, 414 (Diário Catarinense, 2011). Não são números desprezíveis, dado que a média mensal no período 1995-2002 foi de 3,47, e no período 2003-10 foi de 4,31 MPs editadas. São valores expressivos se considerado que o fato gerador deve ser urgente e relevante.

A eficácia imediata e o rito sumário das MPs rompem por completo com os princípios que devem orientar o processo legislativo democrático, a exemplo do amplo debate, não só no Congresso, mas nas e entre as demais representações da sociedade, que deve anteceder a edição da norma legal. Ao trazer para si a responsabilidade do texto, em temas não urgentes e nem relevantes, o Executivo usurpa uma competência originária do Legislativo, atribuindo e concentrando em um pequeno grupo o poder de legislar. Tal fato, por si, gera grandes repercussões na sociedade, algumas, em razão da natureza da maté- 
ria, de caráter irreversível (dado a eficácia imediata) e, por isso, praticamente compelindo o Legislativo a convertê-las em lei. Com isso, perde, também, a democracia representativa.

Cabe esclarecer que a responsabilidade pela edição de MP não deve ser atribuída apenas ao Executivo, devendo ser compartilhada com o Legislativo, pois o $\S 9^{\circ}$ do art. 62 da CF estabelece que "caberá à comissão mista de Deputados e Senadores examinar as medidas provisórias e sobre elas emitir parecer, antes de serem apreciadas, em sessão separada, pelo plenário de cada uma das Casas do Congresso Nacional" (Brasil, 2005:65). Destarte, o que é urgente e relevante pressuposto constitucional, portanto, condição sine qua non para ser matéria de trato por MP, depende inicialmente do entendimento manifesto pelo Executivo (quando edita) e, posteriormente, pelo Legislativo, de modo que este divide com aquele a responsabilidade - se o primeiro é responsável pela edição, o segundo o é por sua admissibilidade e posterior conversão em lei. Há, pois, indubitavelmente, mais do que uma corresponsabilidade, uma efetiva cumplicidade na manutenção desta via do processo legislativo. Entretanto, os dois poderes, no que tange aos ônus, se revelam irresponsáveis, sempre os repassando um ao outro; assim, o Legislativo acusa o Executivo de usurpar suas prerrogativas, e este, àquele de inércia, pois não produz, tempestivamente, o aparato legal e necessário à gestão do governo.

Outro motivo de atritos e impasses é o que determina o § 6o: "Se a medida provisória não for apreciada em até 45 dias contados da sua publicação, entrará em regime de urgência [...] ficando sobrestadas [...] todas as demais deliberações legislativas da Casa em que estiver tramitando" (Brasil, 2005:65). Assim, se frequentes, como têm sido, através das MPs o Poder Executivo não só determina a pauta de prioridades do Legislativo como dificulta que este estabeleça sua própria agenda.

Portanto, diz-se, por esses fatos, que há uma concentração de poderes no Executivo, pois este, além de exercer suas competências constitucionais, avança nos domínios do Legislativo. As acusações e tensões entre os poderes já foram maiores, tendo sido minimizadas a partir da Emenda Constitucional no 32, de 11 de setembro de 2001 (Brasil, 2005) (que introduziu o modus operandi supracitado), pois, anteriormente, as MPs podiam ser reeditadas sem alteração e sem limite de vezes antes de sua apreciação pelo Congresso, como foi o caso da introdução do real como moeda nacional.

Assim, seja motivado pelo desenho institucional, ora pelas práticas individuais, algumas tidas como efetivos desvios, o fato é que a produção legisla- 
tiva originária e relevante no poder instituído para tal tem deixado a desejar. Poder-se-ia arguir, também, acerca da qualidade legislativa a partir das demandas junto ao STF; todavia, é sabido que alguns questionamentos levados à corte têm, por detrás, o interesse na judicialização de um tema que, ainda que essencialmente da esfera política, levado à corte ganha espaço na mídia e até um eventual e importante aliado.

\section{Quando o Judiciário usurpa o poder legiferante}

No curso desse vácuo legislativo, o terceiro poder, o Judiciário, quando chamado a se pronunciar sobre os mais diversos temas, na ausência de norma específica, seja através da hermenêutica, ou da reinterpretação atualizada aos novos fatos e tempos, estabelece a jurisprudência e, em o fazendo, por vezes, segundo alguns, também avança sobre o domínio exclusivo do Legislativo. Em que pese estar à busca de soluções para as divergências que lhe são demandadas, o Judiciário acaba por reafirmar os desvios e a troca de papéis já identificada entre o Executivo e o Legislativo. Como esperado, esse avanço também provoca atritos e reações, registrando-se acusações recíprocas: o Judiciário afirmando a omissão legislativa e o consequente débito do Legislativo junto à sociedade, e este, de aquele agir com ativismo, quando não com pretensões políticas, argumento reforçado pelo fato de alguns magistrados, ao se aproximarem da aposentadoria compulsória, manifestarem pretensões políticas, por nomeação ou indicação, inclusive no caso de egressos da suprema corte.

Ademais, a polêmica não se restringe às disputas entre os poderes, havendo divergências no próprio Judiciário; de um lado há os que defendem que mesmo que a lei esteja defasada e sua aplicação traga efeitos nocivos à sociedade, não cabe à magistratura avançar no campo do legislador, pois, quando entender necessário, a sociedade situará em nível de prioridade e demandará dos representantes a devida atualização da lei; até lá, cumpra-se com fidelidade o texto da norma legal, até como estratégia para forçar a sua atualização. Se, até agora, o Legislativo, pressionado ou não pela sociedade, assim não procedeu, é porque o assunto não reúne o entendimento sobre a urgência e a relevância que parcela do Judiciário lhe tem (indevidamente) conferido. De outro lado, há os que argumentam no sentido de que as instituições legislativas do estado democrático de direito não conseguem responder a contento as demandas da nova sociedade, caracterizada por sua complexidade, velocidade, ambiguidade, conformação em redes, crescente interdependência entre agentes locais e externos, entre outros aspectos, circunstâncias que exigem, 
então, uma nova postura (e ação política) das demais instituições, a exemplo do Judiciário e, no caso brasileiro, também do Ministério Público (Pinheiro, 2004).

Com a cautela que o assunto exige, observa-se uma relativa desarmonia entre os poderes, contrariando, assim, a própria Constituição Federal, escrita de acordo com os princípios republicanos da tripartição de poderes e que adotou o sistema presidencialista de governo. Na sequência, algumas outras iniciativas do Poder Judiciário que estão por trás das áreas de atrito que este mantém com o Legislativo.

\subsection{0 caso do número de representantes nas câmaras municipais}

Em que pese matérias já referidas serem consideradas urgentes e relevantes a partir de quaisquer critérios a serem considerados, é quando entram nas áreas de interesse direto do Poder Legislativo que as manifestações do Judiciário têm enfrentado sua crítica aberta, como foi o caso, entre outros, da alteração no número de vereadores (representantes municipais) nas cerca de 5.500 câmaras municipais existentes no país. Para melhor entendimento, é necessário um breve histórico.

A redação original do art. 29, inciso IV, da CF estabelecia como preceito específico:

[...] número de vereadores [será] proporcional à população do Município, observados os seguintes limites:

a) mínimo de nove e máximo de vinte e um nos Municípios de até um milhão de habitantes;

b) mínimo de trinta e três e máximo de quarenta e um nos Municípios de mais de um milhão e menos de cinco milhões de habitantes;

c) mínimo de quarenta e dois e máximo de cinquenta e cinco nos Municípios de mais de cinco milhões de habitantes (Brasil, 2005:35).

Embora apenas três faixas tenham sido discriminadas, parece inequívoca a intenção do legislador de que a proporcionalidade fosse também observada internamente a cada faixa; por exemplo, no caso da hipótese: a) que municípios menos populosos tivessem nove vereadores, e cabendo aos mais populosos e próximos ao extremo (um milhão de habitantes) a representação pelo limite máximo (21). Contudo, não foi o que ocorreu, tendo-se registrado, em várias municipalidades brasileiras, iniciativas no sentido de ratificar a representação pelo limite máximo. O argumento, ao amparo da independência 
do Poder Legislativo e de sua autonomia administrativa, era de que a iniciativa não contrariava a lei, ao contrário, estava autorizada pela CF. Tal fato, amplamente divulgado pelas mídias, aliado aos desequilíbrios orçamentários enfrentados pela maioria dos municípios, trouxe indignação à população, 0 que levou o Ministério Público a reagir, dando início a ações judiciais contrárias às iniciativas.

O caso mais notório foi o de Erechim, município do interior do estado do Rio Grande do Sul, porque foi a primeira ação que chegou à última instância, portanto, sem mais possibilidade de recurso: o juízo do mérito por parte do STF. À época, 2002, segundo o órgão recenseador oficial, o Instituto Brasileiro de Geografia e Estatística (IBGE), o município contava com 87 mil habitantes; não obstante, os integrantes da câmara decidiram ampliar a representação de nove para 21 vereadores. A reação do Ministério Público, impetrando uma Ação Civil Pública, foi imediata. Finalmente, em outubro de 2003 ocorreu a decisão definitiva: a Câmara deveria voltar atrás, isto é, retornar ao número de nove representantes, pois estava sendo ferido o princípio da moralidade. Outras municipalidades, a exemplo de Parobé, também no Rio Grande do Sul, mais cautelosas, adotaram a estratégia de parcelar a ampliação: em 2003, de 11 para 13, e em 2005, de 13 para 15; todavia, a reação do Ministério Público e a decisão foram no mesmo sentido da anterior.

Considerando que as decisões judiciais podem variar conforme a interpretação de cada juiz ou, em nível de recurso, de cada tribunal, a solução em definitivo demandava a manifestação do Legislativo, posto que seria necessário modificar a Constituição Federal para impedir tais abusos; todavia, a resposta foi o silêncio. Destarte, em abril de 2004, às vésperas de uma nova eleição, o Tribunal Superior Eleitoral (TSE) editou a Resolução no 21.702 (Brasil, 2004) estabelecendo que nas eleições municipais de 2004 a fixação do número de vereadores que seriam eleitos observaria o definido pelo STF em julgamento sobre o tema.

Foram criadas, assim, 36 faixas que adequavam o número de representantes ao da população municipal; com isso, algumas municipalidades, inclusive, tiveram aumentado seu efetivo de eleitos, embora a maioria tivesse experimentado redução. Em que pese o "convite" dos magistrados aos legisladores ter ocorrido em 2004, somente em setembro de 2009, após decorridas duas outras eleições municipais, foi promulgada a Emenda Constitucional no 58 (Brasil, 2009), que determinou 24 faixas para o estabelecimento do número de vereadores, sendo previsto que sua aplicabilidade retroagiria aos resultados das eleições do ano de 2008. O resultado da aprovação de um texto que surpreendentemente modificava o resultado de eleições já ocorridas foi a suspensão pelo STF da posse de milhares de novos vereadores (o que, além de 
modificar os resultados legítimos de uma eleição, teria reflexos orçamentários e políticos em todos os municípios), e que a proporcionalidade disposta na EC no 58 só valeria para as eleições de 2012 (STF, 2009).

\subsection{0 caso das alianças e das coligações de conveniência}

Preliminarmente, cabe lembrar que o Brasil, pelo fato de possuir dimensões continentais, apresenta grande diversidade de características: geográficas (clima, relevo, recursos naturais etc.), de ocupação e formação histórica (há áreas em que predominam imigrantes das mais diversas origens, outras em que determinadas etnias se apresentam concentradas, comunidades em que a mão de obra escrava foi predominante, áreas ainda hoje ocupadas pelos indígenas, regiões historicamente marcadas por sucessivos conflitos de ocupação etc.) e, como resultado desses e de outros fatores, a exploração econômica e a formação social também se verificaram muito distintas.

Atualmente, há no país dois ciclos eleitorais: a cada quadriênio, alternadamente, são eleitos: 1. o presidente da República e os membros do Congresso Nacional (deputados federais e senadores - aqueles representantes da população, estes, dos estados-membros), os governadores e os representantes para as assembleias locais (denominados deputados estaduais); e, dois anos após, 2. os executivos municipais (prefeitos) e os representantes para as câmaras municipais (vereadores).

Durante muito tempo tem sido habitual que, devido às acentuadas diferenças que caracterizam as diversas regiões do país, bem como à existência de um grande número de partidos sem qualquer distinção de fundo ideológico ou programático, entre outras razões, as alianças partidárias constituídas para disputar a Presidência e as cadeiras no Congresso não se reproduzem na disputa pelos cargos estaduais (ao governo do estado e à Assembleia Legislativa), situação em que, ao contrário, os partidos agem como acirrados competidores, efetivos inimigos políticos. Acentua-se, assim, o caráter pessoal da disputa, o que traz prejuízos à instituição partidária, ente central do Estado democrático. Os danos se estendem também ao eleitor que, na mesma campanha eleitoral, se vê diante de uma inusitada e confusa situação: em um primeiro momento, o da campanha à Presidência, por exemplo, assistia (nas mídias) a duas lideranças políticas (de partidos distintos) tecendo loas e hipotecando apoio ao mesmo candidato, porque fiel representante de um ideário e de uma proposta em comum; mas, imediatamente, no momento subsequente (por exemplo, no rádio ou na TV), assistia às mesmas lideranças, mas agora tendo como 
foco a disputa estadual, apoiar candidatos distintos e mesmo acentuando as diferenças programáticas que os distinguiam. Nesse quadro, que no mínimo pode ser dito confuso porque escapa ao entendimento do eleitor mediano, o desestímulo à participação política tende a crescer. Destarte, em 2002, mediante a consulta de um parlamentar insatisfeito com a situação, o TSE assim se manifestou (Brasil, 2002:1):

os partidos políticos que deliberarem sobre coligação para eleição de presidente da república não poderão formar coligações para eleição de governador de estado ou do distrito federal, senador, deputado federal e deputado estadual ou distrital com outros partidos políticos que tenham, isoladamente ou em aliança diversa, lançado candidato à eleição presidencial. Nesse entendimento, o tribunal, por maioria, respondeu negativamente à consulta [...] Os partidos políticos possuem caráter nacional (art.17, I, da Constituição Federal), além de terem legitimidade para a propositura de ação de inconstitucionalidade (art. 103 da CF) e, nesta linha de raciocínio, entende-se que a denominada verticalização das coligações está a atender o ideal sistema de fortalecimento das agremiações partidárias, pois não deixa de impor uma consciência valorativa aos programas gerais daquele grupo como uma efetiva aglutinação de propósitos voltados para a defesa da nação.

Sem dúvida que o pronunciamento da corte, embora em resposta à consulta, em nada agradou o Parlamento, pois significou restrições aos graus de "liberdade política" dos partidos. De modo a preencher o vácuo legislativo, o Congresso aprovou, em março de 2006, a Emenda Constitucional no 52 (Brasil, 2006), que acabou com a verticalização. Contudo, novamente coube ao STF limitar o casuísmo legislativo. Dada a data da promulgação da alteração constitucional, coube à suprema corte assegurar que a verticalização valeria para o pleito de 2006 em respeito ao princípio da anterioridade eleitoral (que estabelece que as normas para uma eleição devem ser definidas no máximo um ano antes do pleito) (STF, 2006).

Por fim e pelos motivos expostos na introdução desta seção, retorna a discussão se não seria o caso de o país voltar a adotar partidos regionais em vez de nacionais, pois, se o Legislativo concertou em favor de seus interesses mais imediatos, resta consertar os danos que o modelo atual conduz no processo de formação da opinião, análise de alternativas e avaliação do eleitorado.

A esses exemplos outros casos ainda poderiam ser alinhados, como foi a manifestação do TSE acerca da (in)fidelidade partidária, para ilustrar como e quanto um poder adentra na esfera de competência do outro, quando este 
se omite. Mais recentemente (Congresso..., 2011:13), a manifestação do STF sobre quem deve assumir a vaga aberta com a licença dos parlamentares, ao lado da proposta de instituir o controle prévio da constitucionalidade das leis, abriu nova frente de conflito entre o Judiciário e o Parlamento, o que sinaliza a urgente necessidade de profundas alterações institucionais. Como se vê, há sinais preocupantes porque indicadores de efetivas tensões entre os poderes.

\section{Algumas considerações críticas}

Que entendimento se pode extrair desses casos e quais seus possíveis desdobramentos?

No que tange ao tema central deste texto, a inversão de papéis entre os poderes da República, parece ser claro que, se em determinadas áreas os limites e as esferas de competência são inequívocos, há outras nas quais as fronteiras permanecem difusas, possibilitando interferências recíprocas ou mesmo, como visto, efetivas inversões em que ora o Executivo, ora o Judiciário, adentram nos domínios do Legistativo.

Tendo-se verificado que é o Legislativo que tem seu espaço invadido, é de se perguntar: por quê? De um lado, são grandes as evidências de que em razão da complexidade de determinadas matérias, como é o caso da taxa de juros (o mesmo se aplicando às pesquisas científicas, a exemplo de outras), elas não deveriam ser estabelecidas a partir do texto constitucional. A consequência pode ser, se não uma impossibilidade de regulamentação, uma grande rigidez quando necessária sua atualização, criando, por isso, um distanciamento entre a carta maior e os atos e fatos da sociedade que deveria regular. De outro, o comportamento de apenas alguns parlamentares é suficiente para imobilizar todo o parlamento: em casa habituada a decidir em colegiado, que por vezes exige maioria (em algum grau) qualificada, é fácil a minoria confrontar e vencer, por obstaculização, a maioria. Mas, se o voto qualificado e a decisão colegiada são procedimentos regimentais concebidos para possibilitar que na análise de cada matéria as múltiplas perspectivas da sociedade fossem contempladas, evitando assim o favorecimento de pequenos grupos e soluções extremadas, não há como negar que são procedimentos que também se prestam à exploração e à defesa de outros interesses.

Se a esses procedimentos regimentais, além dos já comentados, outros elementos do quadro institucional forem adicionados, a exemplo:

v da lista aberta - que valoriza sobremodo o candidato em vez do partido, 
o que confere amplo poder às lideranças, por vezes referida, com humor e ironia, como "alto clero";

v da exclusão dos votos nulos e brancos - não percebidos como protesto explícito do eleitor - para o estabelecimento do quociente eleitoral;

- da proporcionalidade plena para todas as cadeiras do parlamento - o que promove a eleição de "desconhecidos" e dificulta o acompanhamento e a cobrança do eleitor e das representações da sociedade;

- o esprit de corps que predomina no parlamento - como visto nas CPIs e processos de cassação de mandato;

v do foro privilegiado que (quase que) independentemente da natureza do crime é conferido (após autorização das cortes) aos parlamentares;

tem-se um cenário que, se não estimula, facilita o desvio de conduta que se faz acompanhado da quase certeza da sua impunidade, o que parece ser determinante para que alguns integrantes do Legislativo deixem de representar os interesses daqueles que lhes conferiram o poder e o mandato para advogarem em causa própria. Assim, e sem poder de enforcement, o eleitor e a sociedade se tornam reféns da vontade do legislador, que subverte a ordem das matérias a serem apreciadas. Entre outras, uma das regras para definir a agenda de votação é situar entre as primeiras aquelas que reunirem, se não o consenso prévio, a maioria; mas ora, quais as que atendem a essas exigências? As mais simples e de menor relevância (e também de impacto), e as que tratam dos interesses predominantemente corporativos, estas, resguardadas pelo manto da independência dos poderes.

O quadro, como se percebe, é complexo; neste ambiente, as interferências de um poder nos domínios do outro são antes consequência do que fato originário. A solução, já por muitos apontada, seria uma ampla reforma política; esta, a mãe de todas as reformas (da fiscal-tributária, dos direitos e deveres etc.), antes da qual nenhuma outra teria sentido, pois, por antecipação, teria reconhecida sua ineficácia. Contudo, a reforma política, cujo protagonista é o Legislativo, tem encontrado nas normas do próprio Legislativo uma barreira intransponível. As alternativas postas em discussão são de todos conhecidas, pois há as experiências e trajetórias de outros estados-nação que podem contribuir para a reflexão; todavia, o comportamento parlamentar, ainda que de poucos, faz com que o parlamento como um todo se identifique, junto à sociedade, antes de tudo, com a luta pela manutenção do seu status quo, votando para a autopreservação e a defesa dos interesses constituídos, mesmo à 
revelia da manifestação popular. A consequência disso tem sido sobejamente demonstrada nas pesquisas de opinião, que situam o parlamento entre as instituições que gozam de menor prestígio e confiança na sociedade.

Já encaminhando a conclusão, embora não seja o tema principal deste trabalho, mais focado nas questões políticas, não se podem deixar de mencionar outras áreas onde se observam a interferência entre poderes, se não causada pela falta de atualização legislativa, mas também por essa circunstância. Uma delas, a das iniciativas individuais ou coletivas, na forma de ações civis públicas movidas pelo Ministério Público, com o respaldo do Judiciário, para obter o gozo de direitos constitucionais, notadamente relacionados à saúde e à educação, tal como ilustrado por Pinheiro (2004). Desde então, muitos casos têm sido relatados na mídia. O chamado "caos na saúde", segundo alguns, se não resolvido por completo, poderia ser mitigado a partir da regulamentação da Emenda Constitucional no 29/2000; todavia, enquanto isto, o depoimento, em tom de desabafo e alerta, do prefeito de São Gabriel - município do estado do Rio Grande do Sul —, é eloquente, a começar pelo título da matéria — "Um remédio ou veneno?":

vários juristas opinam que não é exatamente tarefa do Judiciário deliberar sobre aquisições que, por alocação de recursos e prioridades, são da alçada do Poder Executivo. Além do aspecto financeiro, há um conflito de competências. O remédio judicial, pelo excesso da dose que vem sendo aplicada nos últimos anos, pode levar muitas prefeituras à falência múltipla de órgãos nos próximos 10 anos (Zero Hora, 19 abr. 2011:19).

Outra matéria, também recente, ilustra a interferência do Judiciário nas atribuições do Executivo do estado do Rio Grande do Sul, onde o juiz titular da $4^{\mathrm{a}}$ Vara Criminal de Canoas negou o pedido de prisão preventiva para os membros de uma suposta quadrilha de assaltantes de caminhões que a polícia acabara de desbaratar. O motivo alegado pelo magistrado foi não haver condições humanas, causadas pela superlotação, nas prisões do estado. Em entrevista ao jornal Zero Hora, o juiz (Irion, 2009) afirmou que "isso é fruto da falta de uma gestão prisional". Na sua edição de 31 de maio, o mesmo Zero Hora, em matéria assinada por Humberto Trezzi (2009), estampou, na seção Polícia, a seguinte chamada: "Justiça dita regras para cadeias gaúchas". E diz o articulista:

O Judiciário desencadeou uma intervenção branca, não ostensiva, nas cadeias gaúchas. Indignados com décadas de protelações no erguimento de presídios, 
juízes despiram a toga e arregaçaram as mangas — no sentido político e prático. Os magistrados são os virtuais gerentes da política prisional, embora esse papel, por lei, seja do Executivo. Como o Estado não cria vagas, desde o ano passado juízes decretaram interdição em 23 prisões. Com isso, obrigam o governo estadual a reformar ou construir presídios. Os magistrados, nesses casos, deixaram de apenas fiscalizar o cumprimento da pena. Eles agora decidem quem entra em que presídio e de que forma.

Com efeito, a partir daquela decisão histórica do juiz da 4⿳a Vara Criminal de Canoas, no dia 27 de maio, o secretário estadual de Segurança Pública declarou que "Queremos anunciar em 90 dias pelo menos um presídio" (Goularte, 2009). Em sua edição de 27 de maio de 2009, o jornal Zero Hora estampava na página da seção Polícia, as seguintes manchetes: "Lotação nas cadeias - Secretário Edson Goularte quer anunciar em 90 dias o começo das obras de um novo presídio gaúcho" e "Estado promete reagir à falta de vagas nas prisões". E na introdução ao texto da matéria informava:

Pressionado com a polêmica causada pela decisão da Justiça de Canoas, na segunda-feira, em recusar a prisão preventiva de 15 suspeitos de furtos de caminhões, devido à superlotação das cadeias gaúchas, o secretário estadual de Segurança Pública (SSP), Edson Goularte, prometeu reagir. Afirmou que, em 90 dias, terá condições de anunciar o início das obras de um novo presídio no Estado (Zero Hora, 2009:38).

Esses episódios evidenciam dois tipos de crise: a primeira é relativa à inoperância do Executivo no cumprimento das suas obrigações constitucionais; a segunda é decorrência da primeira, pois, na falta de ação do Executivo, o Judiciário não só o força a estabelecer e a implementar estratégias de ação, como assume ações que são da competência do Executivo, numa flagrante quebra do ordenamento das competências estabelecidas pela Constituição Federal para os três poderes. Em que pese os últimos exemplos terem sido regionais, essas situações não são acontecimentos meramente pontuais ou excentricidades, mas são, isto sim, resultado de uma grave e profunda crise institucional, como já ficou demonstrado ao longo deste artigo com outros exemplos de amplitude nacional.

O modelo tripartite propaga o equilíbrio dos poderes, sem concentração nem separação absoluta entre eles, o que atualmente não vem ocorrendo no país. Considerando as reflexões aqui apresentadas e que se restringiram ao 
Estado brasileiro, pois nele foram colhidos os exemplos, parece legítimo acrescentar alguns questionamentos: 1 . as liberdades proporcionadas pela democracia não estariam promovendo distorções em determinadas instituições do Estado moderno, a exemplo das funções e das prerrogativas do parlamento, bem como dos partidos políticos, entre outras?; 2. proporcionaria o sistema parlamentarista, se concomitante com outras alterações, melhores respostas aos problemas levantados?; 3. ou o presidencialismo com recall seria uma alternativa para o funcionamento mais harmonioso entre os poderes?; 4) em tempos de recursos que permitem a comunicação (e, por conseguinte, a consulta) instantânea, não deveriam ser revistas as delegações há tanto tempo consagradas nas democracias representativas?; 5. o volume de recursos necessário aos governos nacionais para fazer frente às crises globalizadas (por vezes em tempo recorde), ou mesmo às catástrofes naturais de grande magnitude, não estaria a exigir um repensar sobre as condições e os limites de exigência dos direitos constitucionais?

A resposta a essas, entre outras questões, acredita-se, pode ajudar a superar os conflitos e impasses relacionados; contudo, parece haver indícios de que as instituições que amparam o modelo de Estado-nação da era moderna dão sinais de esgotamento, a começar pela proposta de Montesquieu.

\section{Referências}

AMORIM NETO, Octávio. O Poder Executivo, centro de gravidade do sistema político brasileiro. In: AVELAR, Lúcia; CINTRA, Antônio Octávio (Org.). Sistema político brasileiro: uma introdução. 2. ed. São Paulo: Unesp, 2007. p. 131-141.

ARISTÓTELES. A política. João Pessoa: Escala Educacional, 2006.

ARON, Raymond. As etapas do pensamento sociológico. São Paulo: Martins Fontes, 2002.

AZAMBUJA, Darcy. Teoria geral do estado. 25. ed. Porto Alegre: Globo, 1986.

BRASIL. Câmara dos Deputados. Bancada dos partidos. Câmara dos Deputados. Disponível em: <www.camara.gov.br/Internet/Deputado/bancada.asp>. Acesso em: 10 mar. 2011b.

BRASIL. Constituição. 1988. Emenda Constitucional nº 52, 8 mar. 2006. Presidência da República. Disponível em: <http://www.planalto.gov.br/ccivil_03/constituicao/emendas/emc/emc52.htm>. Acesso em: 12 mar. 2011. 
BRASIL. Constituição. 1988. Emenda Constitucional nº 58, 23 set. 2009. Presidência da República. Disponível em: <www.planalto.gov.br/ccivil_03/constituicao/Emendas/Emc/emc58.htm>. Acesso em: 12 mar. 2011.

BRASIL. Constituição da República Federativa do Brasil. 5 out. 1988. Atualizada até a Emenda Constitucional no 45, de 8 dez. 2004, acompanhada de notas remissivas e dos textos integrais das Emendas Constitucionais e Emendas Constitucionais de Revisão. 35. ed. atual. ampl. São Paulo: Saraiva, 2005.

BRASIL. Lei n 9.096, 19 set. 1995. Dispõe sobre partidos políticos, regulamenta os artigos 14 e 17, § 3o, inciso V, da Constituição Federal. Presidência da República. Disponível em: <www.planalto.gov.br/ccivil_03/Leis/L9096.htm>. Acesso em: 3 mar. 2009.

BRASIL. Senado Federal. Senadoras e senadores em exercício, ordenados por partidos. Senado Federal. Disponível em: <www.senado.gov.br/sf/senadores/senadores_atual.asp?o $=1 \& \mathrm{u}=* \& \mathrm{p}=*>$. Acesso em: 10 mar. 2011c.

BRASIL. Tribunal Superior Eleitoral. Consulta № 715, 26 fev. 2002. TSE. Disponível em: <www.tse.gov.br/sadJudSjur/pesquisa/actionBRSSearch.do?toc $=$ true \&docIndex $=0$ \&httpSessionName $=$ brsstateSJUT24606908\&sectionServer $=$ TSE $>$. Acesso em: 3 mar. 2009.

BRASIL. Tribunal Superior Eleitoral. Partidos políticos registrados no TSE. Tribunal Superior Eleitoral. Disponível em: <www.tse.jus.br/internet/partidos/index. htm >. Acesso em: 10 mar. 2011a.

BRASIL. Tribunal Superior Eleitoral. Resolução no 21.702, 2 abr. 2004. Instruções sobre o número de vereadores a eleger segundo a população de cada município. Tribunal Superior Eleitoral. Disponível em: <www.tse.gov.br/sadJudLegislacao/ pesquisa/actionBRSSearch.do $>$. Acesso em: 3 mar. 2009.

CINTRA, Antônio Octávio. O sistema de governo no Brasil. In: AVELAR, Lúcia; CINTRA, Antônio Octávio (Org.). Sistema político brasileiro: uma introdução. 2. ed. São Paulo: Unesp, 2007. p. 59-79.

CONGRESSO quer frear STF. Zero Hora, Porto Alegre, 24 abr. 2011. p. 13.

ESTADO promete reagir à falta de vagas nas prisões. Zero Hora, Porto Alegre, 27 maio 2009. Seção Polícia, p. 38.

GOULARTE, Edson. Queremos anunciar em 90 dias pelo menos um presídio. Zero Hora, Porto Alegre, 27 maio 2009. Seção Polícia, p. 38.

IRION, Paulo Augusto Oliveira. Porto Alegre. Zero Hora, Porto Alegre, 27 maio 2009. Seção Polícia, entrevista, p. 39.

LOCKE, John. Segundo tratado sobre o governo. São Paulo: Martin Claret, 2006. 
MECANISMO divide os estudiosos. Diário Catarinense, Florianópolis, 17 jan. 2011. Disponível em: <www.clicrbs.com.br/diariocatarinense/jsp/default2.jsp?uf=2\&lo $\mathrm{cal}=18 \&$ source $=$ a3177755. $x$ ml\&template $=3898$. dwt\&edition $=16312 \&$ section $=1$ 34>. Acesso em: 11 mar. 2011.

MENEZES, Aderson de. Teoria geral do Estado. 8. ed. rev. atual. Rio de Janeiro: Forense, 1996.

MILL, John Stuart. O governo representativo. São Paulo: Escala, 2006.

MONTESQUIEU, Charles Louis de Secondat. Do espírito das leis. São Paulo: Martin Claret, 2006.

MORAES, Alexandre de. Presidencialismo. São Paulo: Atlas, 2004.

PINHEIRO, Ivan. A. O Ministério Público enquanto Poder Executivo. REAd - Revista Eletrônica da Administração, Porto Alegre, v. 10, n. 5, 2004. Disponível em: <www. read.ea.ufrgs.br/>. Acesso em: 1ำ fev. 2009.

PRADO, Ney. Razões das virtudes e vícios da Constituição de 1988. São Paulo: Inconfidentes, 1994.

SOUZA JUNIOR, Cezar Saldanha. O Tribunal Constitucional como poder: uma nova teoria da divisão dos poderes. São Paulo: Memória Jurídica, 2002.

SUPREMO TRIBUNAL FEDERAL. STF confirma liminar que suspendeu posse de vereadores. Notícias do STF, 11 nov. 2009. Disponível em: <www.stf.jus.br/por$\mathrm{tal} / \mathrm{cms} /$ verNoticiaDetalhe.asp?idConteudo $=115959 \&$ caixaBusca $=\mathrm{N}>$. Acesso em: 12 mar. 2011.

SUPREMO TRIBUNAL FEDERAL. Supremo mantém verticalização para as eleições de 2006. Notícias do STF, 22 mar. 2006. Disponível em: <www.stf.jus.br/portal/ $\mathrm{cms} /$ verNoticiaDetalhe.asp? $\mathrm{idConteudo}=66612 \&$ caixaBusca $=\mathrm{N}>$. Acesso em: 12 mar. 2011.

TREZZI, Humberto. Presídios - superlotação estimula magistrados a assumirem tarefas que deveriam ser cumpridas pelo governo - Justiça dita regras para cadeias gaúchas. Zero Hora, Porto Alegre, 31 maio 2009. Seção Polícia, p. 41.

ZERO HORA. Porto Alegre, 19 abr. 2011. p. 19.

ZERO HORA. Porto Alegre, 27 maio 2009, p. 38. 
